\title{
Effect of climate change scenarios on yield and water balance components in rice- wheat cropping system in Central Punjab, India
}

\author{
MEHRAJ U DIN DAR *, RAJAN AGGARWAL and SAMANPREET KAUR
}

Department of Soil and Water Engineering, PAU, Ludhiana- 141004, India

*Email: mehrajudindar24@gmail.com

\begin{abstract}
The study focuses on simulating the effect of climate change under RCP4.5 scenario on irrigation requirements,crop yield, crop duration, and water -use efficiency of rice-wheat cropping system with DSSAT v 4.6.1 model at Ludhiana. Model simulations predict reduction in irrigation requirements for rice crop and increase in irrigation requirements for wheat crop under RCP 4.5 scenarios. Also reductions in crop yields in future associated with shortening of growth period due to increased temperature were predicted by the model. Increased rainfall in future would decrease irrigation water requirement of crops but would not offset the adverse effect of increased temperature. Although evapotranspiration would decrease towards end of the century, yet relatively more decrease in yield would lower water use efficiency.
\end{abstract}

Keywords: Climate change scenarios, bias correction functions, DSSAT, rice-wheat cropping system

The changes in climate parameters are being felt globally in the form of changes in temperature and rainfall pattern. For Indian region, Chaturvedi et al., (2012) projected mean warming ranging from of $2^{\circ} \mathrm{C}(\mathrm{RCP} 2.6)$ to $4.8^{\circ} \mathrm{C}$ (RCP8.5) from 1880 s to 2080 s through CPIMP5 model ensemble based projections. All India precipitation is projected to increase by $6,10,9$ and 14 per cent under the scenarios RCP2.6, RCP4.5, RCP6.0 and RCP8.5 respectively, by 2080 s relative to the 1961-1990 baseline, whereas much larger variability will be seen in the spatial distribution. The emerging scene of agriculture in Punjab is facing some serious concerns. Green revolution sustained till the eighties, after which the agricultural production in the state showed the signs of stagnation. This was largely attributed to continuous cultivation of rice wheat cropping system having negative implications for soil quality (nutrient balance), infestation of weeds and pests. The issue of overexploitation of groundwater is more concentrated mostly in central Punjab. Under climate change scenario daily weather data is generally derived from general circulation models (GCM) and/or regional climate models (RCM). Zacharias et al., (2015) used the climatic outputs of an RCM-PRECIS (providing regional climates for impact studies) model to analyze baseline simulation daily weather data on temperature and precipitation patterns with the observed weather for the corresponding period (1960-1990) in order to find out the bias in the model. To study the impact of changing climate, numbers of crop models are available in the literature but the models like Decision Support System for Agro Technology Transfer (DSSAT), InfoCrop and cropping system simulation (CropSyst) are widely used because these models assess the effects of $\mathrm{CO}_{2}$ and weather parameters on crop growth, biomass, water balance, nitrogen balance on daily basis. The present study was undertaken with the objectives to (i) obtain climate data on maximum temperature $\left(\mathrm{T}_{\max }\right)$, minimum temperature $\left(\mathrm{T}_{\min }\right)$ and rainfall (RF) for baseline and future from HAD GEM2-ES GCMmodel under RCP 4.5and to (ii) assess the effect of climate change scenario on water requirements, productivity and water use efficiency of rice-wheat system in climatic conditions of Ludhiana Punjab, India.

\section{MATERIALS AND METHODS}

\section{Study site and climate}

The study was carried out for Ludhiana (75 $\square 52 \square$ Elongitude and 30 $\square 56 \square \mathrm{N}$ latitude) in the Punjab state of India. Past 46 years (1970-2015) daily weather data on rainfall (RF), $\mathrm{T}_{\max }$ and $\mathrm{T}_{\min }$ recorded at meteorological observatory were used. Climate change RCP 4.5 scenario data for $\mathrm{T}_{\max }, \mathrm{T}_{\min }$ and RF was derived from HAD GEM2-ESGeneral circulation model on daily basis for Ludhiana for time period of 1970-2015 (baseline), 2020-2050 (midcentury) and 2060-2090 (end-century). Biases in $\mathrm{T}_{\max }, \mathrm{T}_{\min }$ and RF data were evaluated for monthly trends and statistical parameters like mean, standard deviation and variance. The biases were minimized by applying correction functions developed from observed and modelled data of years from 
Table 1: Statistical parameters of modelled and observed temperatures and rainfall

\begin{tabular}{|c|c|c|c|c|c|c|}
\hline \multirow{2}{*}{$\begin{array}{l}\text { Statistical } \\
\text { parameter }\end{array}$} & \multicolumn{2}{|c|}{$\mathrm{T}_{\max }\left({ }^{\circ} \mathrm{C}\right)$} & \multicolumn{2}{|c|}{$\mathrm{T}_{\min }\left({ }^{\circ} \mathrm{C}\right)$} & \multicolumn{2}{|c|}{ Rainfall, $\left(\mathrm{mmday}^{-1}\right)$} \\
\hline & Modelled & Observed & Modelled & Observed & Modelled & Observed \\
\hline Mean & 31.7 & 30.0 & 17.8 & 17.6 & 2.8 & 2.0 \\
\hline SD & 7.8 & 8.6 & 9.4 & 8.1 & 5.1 & 6.8 \\
\hline Variance & 60.8 & 73.9 & 88.3 & 65.2 & 26.3 & 46.2 \\
\hline
\end{tabular}

2010 to 2015 , as it was producing the least error between the observed and modelled data after the application of correction functions and validated on the data for randomly selected two years. Linear scaling method for development of correction functions at monthly scale (Lenderink et al., 2007) was used.

\section{Crop simulation model}

Simulations for irrigation requirements, yield, crop duration and water balance were run using DSSAT v 4.6.1 model (Hoogenboom et al., 2015). This model had already been intensively parameterized with the experimental data observed at the Research Farm, Punjab Agricultural University, Ludhiana, $\left(30^{\circ} 56 \square \mathrm{N}, 75^{\circ} 52 \square \mathrm{E}\right.$ and $247 \mathrm{~m}$ above mean sea level) in central Punjab during year of 2005, 2011 and 2013 and the experimental details of treatments, soil conditions and management practices for these experiments are given elsewhere (Jalota et al., 2006, 2009). Simulations were made for normal planting dates i.e. June 10 for rice (variety PR121) and November 5 for wheat (variety PBW 343). Validation and performance of the model have already been discussed elsewhere (Jalota et al., 2012).Using baseline, mid-century (MC) and end-century (EC) daily weather data, crop growth durations (planting to physiological maturity), yields and water balance components were simulated for rice-wheat system with $\mathrm{CO}_{2}$ levels for a given year and scenario as per (IPCC., 2013).

Water use efficiency (WUE) was calculated

WUE $\left(\operatorname{kg~m}^{\prime \prime}\right)=\frac{\text { grain yield }}{\text { evapotranspiration }}$

\section{RESULTS AND DISCUSSION}

\section{Typical biases of HAD GEM2-ES}

Monthlyaverages of 6 years (2010-2015) of the observed and GCM-HAD GEM2 ES modelled maximum temperature $\left(\mathrm{T}_{\max }\right)$ and minimum temperature $\left(\mathrm{T}_{\min }\right)$ for the location showed that the modelled temperature approximately represented the observed seasonal cycle. However, the modelled values of $\mathrm{T}_{\text {max }}$ were slightly higher than that of the observed (Table 1). The analysis of the
Table 2: Annual based climate predictions for the three time slices of the future weather for Ludhiana district under RCP 4.5

\begin{tabular}{lrrr}
\hline & $\begin{array}{r}\text { Baseline } \\
(1970-2015)\end{array}$ & $\begin{array}{r}\text { Mid-century } \\
(2020-2050)\end{array}$ & $\begin{array}{r}\text { End century } \\
(2060-2090)\end{array}$ \\
\hline Annual T $_{\text {max }}\left({ }^{\circ} \mathrm{C}\right)$ & 29.7 & 31.0 & 33.1 \\
Annual T $_{\text {min }}\left({ }^{\circ} \mathrm{C}\right)$ & 16.6 & 18.4 & 19.5 \\
Mean $\left({ }^{\circ} \mathrm{C}\right)$ & 23.2 & 24.7 & 26.3 \\
Rain $(\mathrm{mm})$ & 759.8 & 662.2 & 670.1 \\
\hline
\end{tabular}

Table 3: Average duration for rice and wheat crop in baseline, mid-century (MC) and end century (EC) for Ludhiana district under RCP 4.5

\begin{tabular}{llll}
\hline Crop & $\begin{array}{l}\text { Baseline } \\
(1970-2015)\end{array}$ & $\begin{array}{l}\text { Mid-century } \\
(2020-2050)\end{array}$ & $\begin{array}{l}\text { End century } \\
(2060-2090)\end{array}$ \\
\hline Rice & 120 & 115 & 113 \\
Wheat & 167 & 161 & 158 \\
\hline
\end{tabular}

statistical parameters i.e., annual mean, standard deviation (SD) and variance of $\mathrm{T}_{\max }$ showed that the mean of the modelled $\mathrm{T}_{\max }$ was $1.7^{\circ} \mathrm{C}$ more than that of the observed while as $\mathrm{SD}$ of modelled $\mathrm{T}_{\text {max }}$ was $0.8^{\circ} \mathrm{C}$ less than that of observed $\mathrm{T}_{\max }$ data. In $\mathrm{T}_{\text {min }}$ mean of modelled and observed were comparable but $\tilde{\mathrm{A}}$ was $1.2^{\circ} \mathrm{C}$ more in the modelled data than observed $\mathrm{T}_{\min }$. In case of rainfall, mean of the modelled rainfall was $0.8 \mathrm{~mm}$ day $^{-1}$ more than that of the observed (Table 1).

\section{Climate change scenarios}

In the baseline the average \pm standard deviation of $R F$ was $759.8 \pm 227.1 \mathrm{~mm}$, which decreased to $662.2 \pm 49.7 \mathrm{~mm}$ in MC and 670.1 $\pm 39.3 \mathrm{~mm}$ in EC under RCP 4.5. In case of $\mathrm{T}_{\max }$ it was $29.7 \pm 0.5^{\circ} \mathrm{C}$ for the baseline of the century and rose to $31.1 \pm 0.4^{\circ} \mathrm{C}$ in $\mathrm{MC}$ and $33.1 \pm 0.3^{\circ} \mathrm{C}$ in $\mathrm{EC}$. Correspondingly, $\mathrm{T}_{\text {min }}$ of $16.6 \pm 0.8^{\circ} \mathrm{C}$ of baseline would increase to $18.4 \pm 0.3^{\circ} \mathrm{C}$ in $\mathrm{MC}$ and $19.5 \pm 0.2^{\circ} \mathrm{C}$ in EC. This indicated that mean annual temperature would increase by $1.5^{\circ} \mathrm{C}$ in $\mathrm{MC}$ and $3.1^{\circ} \mathrm{C}$ in $\mathrm{EC}$ compared to that of the baseline period, respectively. The corresponding likely decrease in annual RF under RCP 4.5 is $97.6 \mathrm{~mm}$ and 89.7 $\mathrm{mm}$, respectively (Table 2 ). 
Table 4: Simulated yield, water balance components and- use efficiency of rice and wheat crops as influenced by different time slices of the $21^{\text {st }}$ century and soil texture under RCP 4.5

\begin{tabular}{|c|c|c|c|c|c|c|}
\hline Time slice & Yield $\left(\mathrm{kg} \mathrm{ha}^{-1}\right)$ & $\begin{array}{l}\text { Evapotranspiration } \\
(\mathrm{mm})\end{array}$ & $\begin{array}{l}\text { Irrigation } \\
(\mathrm{mm})\end{array}$ & $\begin{array}{l}\text { Rainfall } \\
(\mathrm{mm})\end{array}$ & $\begin{array}{l}\text { Drainage } \\
(\mathrm{mm})\end{array}$ & $\begin{array}{l}\text { WUE } \\
\left(\mathrm{kgm}^{-3}\right)\end{array}$ \\
\hline \multicolumn{7}{|c|}{ Rice } \\
\hline Baseline & 6419 & 550.3 & 1495.3 & 595.6 & 1164.8 & 1.1 \\
\hline Mid century & 6222 & 541.2 & 1367.2 & 541.5 & 949.5 & 1.1 \\
\hline End century & 6316 & 592.9 & 1385.1 & 582.7 & 947.0 & 1.0 \\
\hline \multicolumn{7}{|c|}{ Wheat } \\
\hline Baseline & 5772 & 431.9 & 297.9 & 121.7 & - & 1.3 \\
\hline Mid century & 5661 & 449.6 & 370.6 & 72.3 & - & 1.2 \\
\hline End century & 5092 & 464.7 & 426.4 & 32.0 & - & 1.0 \\
\hline
\end{tabular}

\section{Crop yield and duration}

Simulated crop yields and water balance components of rice and wheat crops in the baseline, $\mathrm{MC}$ and $\mathrm{EC}$ are presented in (Table 4). In baseline the resultant simulated yield was $6419 \mathrm{~kg} \mathrm{ha}^{-1}$ in rice and $5771 \mathrm{~kg} \mathrm{ha"}{ }^{\prime \prime}$ in wheat and was closer to the observed under field conditions ( Jalota $e t$ al., 2009, 2011). Under RCP 4.5, averaged across soil series, yield of rice in MC and EC was reduced by $197 \mathrm{~kg}$ ha" and $103 \mathrm{~kg} \mathrm{ha"1}$, respectively than that in the baseline .Yield of wheat in MC and EC was reduced by $110 \mathrm{~kg}$ ha"1 and $680 \mathrm{~kg}$ ha" ${ }^{\prime}$, respectively than that of baseline. Reduction in yields of rice and wheat crops in different time slices was found to be directly related to increased $\mathrm{T}_{\max }$ and $\mathrm{T}_{\min }$. The resultant crop duration was shortened by 5 days and 7 days in rice; and 6 days and 9 days in wheat in $\mathrm{MC}$ and $\mathrm{EC}$, respectively under RCP 4.5 (Table 3 ). These results bring out that inter year rotation information on crop yields in $\mathrm{MC}$ and EC can only be obtained using HAD GEM2-ES and like models, which provide daily weather data.

\section{Irrigation requirements:}

Under RCP 4.5, irrigation demand for rice in baseline, mid-century (MC) and end century (EC) indicated that irrigation demand was decreasing in all the three time periods due to more rainfall in these periods while in wheat crop less rainfall in these periods has led to increase in demand of irrigation. It was computed for Ludhiana district for rice crop that the annual water requirement would reduce to 1367.2 $\mathrm{mm}(8.6 \%)$ in $\mathrm{MC}$ and $1385.1 \mathrm{~mm}(7.4 \%)$ in EC from the $1495.3 \mathrm{~mm}$ in the baseline. In wheat crop the annual irrigation water requirements would increase to $370.6 \mathrm{~mm}(24.4 \%)$ in $\mathrm{MC}$ and $426.4 \mathrm{~mm}(43.1 \%)$ in EC from the irrigation requirement of $297.9 \mathrm{~mm}$ in the baseline (Table 4).In the MC and EC, water balance components were changed as the crop duration was shortened and RF was decreased under RCP 4.5 compared to that of the baseline. In MC, the RF was decreased by $54 \mathrm{~mm}$ during rice and $49 \mathrm{~mm}$ during wheat crops. The corresponding values in EC were $13 \mathrm{~mm}$ and 90 $\mathrm{mm}$, respectively. As a consequence of fluctuating behavior of rainfall, under this scenario the irrigation requirement in $\mathrm{MC}$ and EC was decreased by 128 and $110 \mathrm{~mm}$ in rice; and increased by 73 and $129 \mathrm{~mm}$ in wheat, respectively. Under RCP 4.5, in MC and EC, ET was decreased by 9 and increased $43 \mathrm{~mm}$ in rice; and increased by 18 and $33 \mathrm{~mm}$ in wheat, respectively. under elevated temperature (Table 4).

\section{CONCLUSIONS}

The present study of the effect of climate change on irrigation requirements, crop productivity and water use efficiency involved use of global climate model (HADGEM2ES) data, its correction with suitable bias correction method and simulation of yield, crop duration and waterbalance with crop simulation model (DSSAT). The results from the present study conclude that in central Punjab temperature will increase by $1.5^{x \% \%} \mathrm{C}$ in mid and by $3.1^{x \%} \mathrm{C}$ in end of the 21 st century under RCP 4.5. The increased temperature would decrease the demand for irrigation in rice crop however an increase in demand of irrigation for wheat crop was predicted by the model, which may be due different rainfall magnitudes during the growing periods of these two crops. The increased temperature reduced yields of rice and wheat crops by shortening their duration. With changed climate not only the irrigation requirements, crop yields would reduce but evapotranspiration and water use efficiency would also decrease. 


\section{REFERENCES}

Chatturvedi R. K., Joshi J., Jayaraman M., Bala, G. and Ravindranath, N.H. (2012). Multi model climate change projections for India under representative concentration pathways. Current Sci.,103: 791802.

Hoogenboom G., Jones J.W., Wilkens P.W., PorterC.H., Boote K.J., Hunt L.A., SinghU., Lizaso J.I., White J.W., Uryasev O., Ogoshi R., Koo J., Shelia, V. and Tsuji G.Y.(2015). Decision Support System for Agrotechnology Transfer (DSSAT) Version 4.6 (http://dssat.net). DSSAT Foundation, Prosser, Washington.

IPCC.(2013) Summary for Policymakers. In: Climate Change 2013: The Physical Science Basis. Contribution of Working Group III to the Fifth Assessment Report of the Intergovernmental Panel on Climate Change.

Jalota S.K., Singh G.B., Ray S.S., Sood, A. and Panigrahy, S. (2006). Performance of Cropsyst model in rice-wheat cropping system. J. Agri. Phy., 6:7-13.

Jalota S.K., Singh K.B., Chahal G.B.S., Gupta R.K., Chakraborty S., SoodA., Ray, S.S.and Panigraphy, S.(2009). Integrated effect of transplanting date, cultivar and irrigation on yield, water saving and water productivity of rice (Oryza sativa L.) in Indian Punjab: field and simulation study. Agri. Water Manage.,96: 1096-1104.

Jalota S.K., VashishtB.B., Kaur H.,Arora V.K., Vashist, K.K.and Deol, K.S.( 2011). Water and nitrogen balance, -use efficiency in rice (Oryza sativa L.)-wheat (Triticumaestivum L.) cropping system as influenced by management interventions: Field and simulation study. Exp. Agri., 47 (4): 609-628.

Jalota S.K., Kaur H., Ray S.S., Tripathy R., Vashisht, B.B. and Bal, S.K.(2012). Mitigating future climate change effects byshifting planting dates of crops in rice-wheat cropping system.Reg. Environ. Change.,http://dx.doi.org/ 10.1007/s10113-012-0300-y.

LenderinkG., Buishand,A. andVan Deursen, W.(2007).Estimates of future discharges of the river Rhine using two scenario methodologies: direct versus delta approach. J. Hydrol. And Earth Sys. Sci., 11: 1145-59.

ZachariasM., Kumar S. N., Singh S. D., Rani, D. S. and Aggarwal, P. K. (2015). Evaluation of a regional climate model for impact assessment of climate change on crop productivity in the tropics. Current Sci., 108(6): 1119. 